\title{
PERAN DAN STRATEGI ORGANISASI NON PEMERINTAH DALAM ARENA POLITIK LINGKUNGAN HIDUP
}

\author{
NGO's Roles and Strategies in the Environmental Politic Arena
}

\author{
David Ardhian*), Soeryo Adiwibowo, dan Ekawati Sri Wahyuni \\ Program Studi Sosiologi Pedesaan, Sekolah Pasca Sarjana, Institut Pertanian Bogor \\ ${ }^{*}$ E-mail: davidardhian@gmail.com
}

\begin{abstract}
NGOs have played increasingly prominent roles and strategies in the environment politic arena. The study was carried out using qualitative approach at national and local to elaborate Indonesia NGOs roles and strategies in responding land and forest fires. The Study reveals that NGOs were be able to take advance of collective deprivations and political opportunities to develop mobilization structure, framing process and various form of actions in responding land and forest fires. NGOs political strategies are directly influence key stakeholders, develop pressure to governmnet using transnational advocacy networks, enhancing market and sustainability standart to private sectors, influencing capital flow, mobilizing elits and promoting best practices at local as alternative solutions. $N G O s$ plays as social movement organization in the frame of new social movement to enhance the equality of power relations, through influencing policies, law enforcement, market and private sectors behaviour, and promoting community-based peatland management model at local, toward better governance of natural resources management in Indonesia.
\end{abstract}

Keywords : NGO, social movement, political ecology, land and forest fire

\begin{abstract}
ABSTRAK
Oganisasi Non Pemerintah (ORNOP) memainkan peran dan strategi penting dalam arena politik lingkungan hidup. Studi dilakukan dengan pendekatan kualitatif untuk menjelaskan peran dan strategi ORNOP di Indonesia pada tingkat nasional dan lokal dalam menanggapi kasus kebakaran hutan dan lahan. Studi mengungkap bahwa ORNOP mampu memanfaatkan keluhan kolektif dan struktur kesempatan politik untuk membangun struktur mobilisasi, proses framing dan bentuk-bentuk aksi. Strategi Politik ORNOP diwujudkan dengan cara mempengaruhi secara langsung pihak-pihak kunci, meningkatkan tekanan politik terhadap pemerintah dengan menggunakan jaringan advokasi lintas negara, mendorong standar keberlanjutan pasar, mempengaruhi aliran kapital, mobilisasi dukungan elit dan mempromosikan praktik-praktik terbaik sebagai solusi tandingan. ORNOP mampu memainkan peran sebagai organisasi gerakan sosial untuk mendorong kesetaraan relasi kuasa, dengan mempengaruhi kebijakan, penegakan hukum, perilaku pasar dan sektor swasta, serta mempromosikan pengelolaan lahan gambut berbasis masyarakat pada tingkat lokal, dalam rangka penguatan tata kelola sumberdaya alam di Indonesia.
\end{abstract}

Kata kunci : organisasi non pemerintah, gerakan sosial, ekologi politik, kebakaran hutan dan lahan

\section{PENDAHULUAN}

\section{Latar Belakang}

Kebakaran hutan dan lahan (karhutla) merupakan salah satu masalah lingkungan hidup yang penting di Indonesia. Karhutla telah terjadi selama 17 tahun terakhir dengan intensitas kejadian semakin tinggi dan dampak semakin luas. Karhutla pada tahun 2015 menghanguskan 2,6 juta hektar lahan dengan kerugian ekonomi diperkirakan mencapai 2,21 triliun rupiah (BD 2015). Laporan dari Global Fire Emissions Database (GFED) tahun 2015 menyatakan bahwa tingkat emisi karbon Indonesia akibat karhutla, pada bulan September sampai Desember 2015 mencapai 15-20 juta ton per hari, yang menempatkan Indonesia sebagai penyumbang emisi karbon terbesar di dunia. Studi Purnomo et al. (2015) mengungkap karhutla telah memberikan dampak sosial bagi 43 juta jiwa penduduk yang terpapar kabut asap, 400 ribu jiwa mengalami sakit gangguan pernafasan dan 12 korban meninggal dunia. Kabut asap yang bergerak melintasi batas negara, juga telah menimbulkan ketegangan politik dengan negara-negara tetangga seperti Malaysia dan Singapura, serta mendapat perhatian luas secara internasional.

Secara awam karhutla dipandang sebagai masalah perubahan biofisik lingkungan hidup dan dampak-dampaknya. Karhutla dilihat sebagai fenomena meluasnya sebaran titik api (hotspot) yang menghanguskan hutan dan lahan terutama pada lahan gambut, serta menimbulkan kabut asap dalam skala luas. Dari sudut pandang ekologi politik, karhutla bukan sekedar masalah biofisik lingkungan hidup namun terkandung didalamnya persoalan ekonomi politik dan relasi kekuasaan.

Blaikie dan Brookfield (1987) menjelaskan bahwa ekologi politik merupakan kombinasi perhatian terhadap ekologi dan ekonomi politik secara luas, yakni dialektika antara masyarakat dengan sumberdaya berbasis lahan, termasuk dialektika antar kelas dan kelompok-kelompok dalam masyarakat. Bryant dan Bailey (1997) menambahkan bahwa ekologi politik mempelajari sumber, kondisi dan implikasi politik dari kerusakan lingkungan hidup, dimana dalam konteks negara berkembang krisis ekologi lebih banyak berpangkal pada ketimpangan relasi kuasa.

Ketidaksetaraan relasi kuasa dalam kasus karhutla, bisa dilacak dari sejarah panjang pembukaan hutan, termasuk hutan rawa gambut, untuk kepentingan pembangunan ekonomi. Meningkatnya kejadian karhutla berhubungan erat dengan ekspansi industri berbasis hutan dan lahan, seperti ekspansi industri kayu sejak tahun 1970-an dan perluasan perkebunan 
kelapa sawit sejak tahun 1990-an. Purnomo et al. (2015) mengungkapkan dimensi ekonomi politik karhutla, dimana peningkatan kebutuhan lahan untuk kebun kelapa sawit dipengaruhi oleh peningkatan permintaan produk kelapa sawit dari pasar global. Karhutla terjadi karena proses pembukaan hutan dalam skala luas, yang didorong oleh motif ekonomi perusahaan untuk membuka lahan dengan cara membakar, serta faktor-faktor yang berkaitan dengan kebijakan pembangunan yang eksploitatif terhadap sumberdaya alam. Karhutla memiliki dimensi dan implikasi politik, dimana aktor-aktor seperti pemerintah dan perusahaan memiliki kuasa dan kapital untuk menentukan pola dan arah pemanfaatan sumberdaya alam, sementara warga masyarakat merupakan pihak yang paling lemah dan menjadi korban dari dampak-dampak yang ditimbulkan oleh karhutla. Karhutla menjadi ajang kontestasi kepentingan politik dari peran, pengaruh dan kepentingan dari aktor-aktor yang terlibat didalamnya, termasuk kalangan Lembaga Swadaya Masyarakat (ORNOP).

Perkembangan ORNOP dalam arena politik lingkungan hidup dilihat sebagai bagian dari proses demokratisasi lingkungan hidup (Princen \&Finger 1994). Sejak Konferensi Bumi yang diselenggarakan di Rio De Jeneiro pada tahun 1992, partisipasi organisasi masyarakat sipil dalam kebijakan lingkungan hidup mengalami perkembangan yang pesat. Perubahan kebijakan dan tata kelola lingkungan hidup tidak lagi hanya berpusat pada aktor-aktor negara, namun juga peran organisasi masyarakat sipil sebagai perwakilan aktor non-negara (Guadalope \&Rodrigues 2014). ORNOP mampu memainkan peran penting dalam diplomasi lingkungan hidup (Betsill \&Corell 2001), mengembangkan jaringan advokasi transnasional dalam menanggapi masalah lingkungan hidup (Keck \&Sikkink 1999) dan mempengaruhi standar keberlanjutan lingkungan hidup sektor swasta (Pasqueira \& Glasbergen 2013). Dengan kata lain, ORNOP merupakan salah satu aktor yang dominan dalam politik lingkungan hidup kontemporer (Carter 2007).

Dari sudut pandang gerakan sosial, perkembangan ORNOP dilihat sebagai salah satu bentuk organisasi gerakan sosial (Porta \& Diani 2006). Perkembangan ORNOP merupakan indikasi dari tumbuhnya gerakan lingkungan hidup global (Carter 2007). Dalam khasanah teori gerakan sosial, gerakan lingkungan hidup merupakan bagian dari Gerakan Sosial Baru (GSB). Gerakan sosial lama memfokuskan pada basis material dan terkait dengan kepentingan kelas atau kelompok sosial tertentu seperti gerakan buruh dan gerakan petani, sementara gerakan sosial baru lebih menekankan pada masalah ide dan nilai serta melibatkan aktor yang lebih plural seperti gerakan feminisme, gerakan hak asasi manusia, gerakan hak asasi manusia termasuk gerakan lingkungan hidup (Rahman 2005). Dengan kata lain gerakan sosial baru menandai perkembangan teori gerakan sosial dari isu redistributif menuju isu kualitas hidup (Sigh 2001).

Di Indonesia, tumbuhnya gerakan lingkungan hidup adalah sebagai reaksi terhadap kebijakan politik ekonomi rezim Orde Baru yang eksploitatif terhadap sumberdaya alam (Peluso et al. 2008). Situmorang (2013) dalam studi dinamika protes kolektif lingkungan hidup 1968-2011 menjelaskan bahwa tumbuh, berkembang dan menurunnya protes kolektif lingkungan hidup tidak bisa dilepaskan dari variabel keluhan kolektif, struktur kesempatan politik, struktur mobilisasi, proses framing dan bentuk-bentuk aksi. Namun demikian penelitian mengenai peran dan strategi ORNOP dalam arena politik lingkungan hidup belum banyak mendapat perhatian. Studi ini bermaksud mengkaitkan antara perspektif ekologi politik dan gerakan sosial, serta implikasinya terhadap perubahan kebijakan dan tata kelola lingkungan hidup di Indonesia. Hal tersebut dipelajari melalui analisis terhadap peran dan strategi ORNOP dalam arena politik lingkungan hidup, dengan mengambil kasus kebakaran hutan dan lahan.

\section{Perumusan Masalah}

Kasus karhutla yang terjadi dalam skala semakin besar dan dampak semakin luas, merupakan indikasi bahwa kebijakan dan tata kelola lingkungan hidup di Indonesia masih belum berubah secara signifikan. Kasus karhutla besar terjadi di Indonesia pada tahun 1982/1983, 1997/1998, 2006/2007 dan terakhir pada tahun 2014/2015 (Purnomo et al. 2015; Panjaitan 2015).

Kasus karhutla adalah sebuah krisis ekologi yang berpangkal pada ketidaksetaraan relasi kuasa diantara aktor yang terlibat didalamnya. Perkembangan kasus karhutla tidak bisa dilepaskan dari ekspansi industri berbasis lahan dan hutan, seperti perkembangan perusahaan kayu (HPH/HTI) sejak tahun 1970-an dan perkebunan kelapa sawit sejak tahun 1990-an. Hal tersebut mengakibatkan pembukaan hutan dalam skala luas, termasuk hutan rawa gambut. Dominasi perusahaan sebagai aktor yang paling berpengaruhi dalam tata kelola hutan dan lahan, mengundang perhatian dari kalangan ORNOP di Indonesia.

ORNOP sebagai salah satu bentuk organisasi gerakan sosial memainkan peran dan strategi dalam rangka mendorong kesetaraan relasi kuasa antara pemerintah, perusahaan dan warga masyarakat. Namun demikian bagaimana peran dan strategi ORNOP dalam menanggapi karhutla belum pernah dilakukan penelitian.

Studi ini bertujuan untuk memberikan gambaran mengenai peran dan strategi ORNOP dalam arena politik lingkungan hidup, pada kasus karhutla di Indonesia. Untuk itu pertanyaan penelitian dalam studi ini dirumuskan sebagai berikut :

1. Bagaimana peran dan strategi organisasi ORNOP dalam menanggapi masalah kebakaran hutan dan lahan pada tingkat lokal dan nasional?

2. Sejauh mana peran ORNOP dalam memperkuat kebijakan dan tata kelola yang lebih baik terkait pengendalian kebakaran hutan dan lahan di Indonesia?

\section{Ruang Lingkup Penelitian}

Dimensi organisasi memegang peranan penting dalam gerakan sosial. Diani dan Porta (2006) mendefinisikan gerakan sosial sebagai sebentuk aksi kolektif dengan orientasi konfliktual yang jelas terhadap lawan sosial dan politik tertentu, dilakukan dalam konteks lintas kelembagaan, oleh aktor-aktor yang diikat rasa solidaritas dan identitas kolektif yang kuat. Secara ringkas elemen-elemen gerakan sosial adalah aksi kolektif yang konfliktual, jaringan informal yang kuat dan adanya identitas kolektif yang sama.

ORNOP merupakan salah satu elemen dalam gerakan sosial (Fakih 1996; Ganie-Rochman 2003; Rahman 2005). Pengertian ORNOP dalam penelitian ini mengacu pada definsi menurut Clark (1998), ORNOP adalah organisasi privat, nirlaba dan profesional dengan kejelasan badan hukum yang menaruh perhatian pada tujuan-tujuan kesejahteraan publik. Diani dan Porta (2006) membedakan organisasi gerakan sosial profesional dan partisipatif. ORNOP merupakan organisasi gerakan sosial profesional yang memililiki ciri-ciri adanya 
unsur-unsur profesionalisme, sistem manajemen dan struktur organisasi yang formal serta kemampuan teknis tertentu untuk kepentingan gerakan.

Salah satu arena yang menjadi perhatian besar dari ornop adalah arena politik lingkungan hidup. Arena politik lingkungan hidup dalam hal ini mengacu pada pendapat Princen dan Finger (1994) dan Carter (2007), mencakup kebijakan, tata kelola dan praktek-praktek pengelolaan lingkungan hidup. Dalam penelitian ini arena politik lingkungan hidup dibatasi pada kasus kebakaran hutan dan lahan.

\section{KERANGKA PEMIKIRAN}

Studi berangkat dari perspektifbahwa karhutla merupakan salah satu bentuk krisis ekologi yang disebabkan oleh ketidaksetaraan relasi kuasa (unequal power relation). Hal tersebut dijelaskan dari sudut pandang ekologi politik bahwa kerusakan ekologi mengandung dimensi ekonomi politik (Blaikie \& Brookfield 1987), dimana untuk kasus negara berkembang lebih banyak berpangkal dari masalah ketimpangan relasi kuasa (Bryant \& Bailey 1997). Ketimpangan relasi kuasa berkaitan dengan kontestasi peran, pengaruh dan kepentingan dari para aktor yang terlibat dalam arena politik lingkungan hidup. Dalam konteks ini maka studi memfokuskan untuk melihat salah satu aktor yang penting dalam arena politiik yakni peran dan strategi ORNOP.

Untuk menganalisis peran dan strategi ORNOP maka studi ini berpijak pada kerangka teori Gerakan Sosial Baru (GSB). Menurut Singh (2001) teori GSB merupakan penjelasan terhadap pergeseran gerakan sosial dari isu redistributif menuju kualitas hidup. GSB berkembang sebagai kritik dari teori-teori gerakan sosial lama yang didominasi oleh kerangka pemikiran Marxian, yang memfokuskan pada konsep perjuangan kelas dengan kaum buruh sebagai pusat perubahan sosial. Gerakan sosial lama dianggap tidak lagi memadai untuk menjelaskan perkembangan gerakan sosial yang memasuki konflik-konflik baru seperti konflik identitas, nilai-nilai dan kultural yang tidak bisa direduksi sebagai konflik proses produksi (Saunders 2013). Saunders (2013) menjelaskan bahwa GSB memiliki karakteristik anti modernisasi, tidak berbasis kelas tertentu dalam masyarakat, tampil dalam bentuk yang partisipatif, tidak hirarkis dan terdesentralisasi, dengan orientasi pada kebebasan dan otonomi masyarakat sipil. Salah satu bentuk GSB adalah gerakan lingkungan hidup.

Studi ini melihat bahwa perkembangan ORNOP sebagai organisasi gerakan lingkungan hidup dilihat dari lensa analisis GSB. Dalam konteks Indonesia, Situmorang (2013) mengembangkan sintesis dari konsep-konsep teori gerakan sosial untuk menganalisis dinamika proses kolektif lingkungan hidup. Konsep-konsep tersebut adalah keluhan kolektif, struktur kesempatan politik, struktur mobilisasi, proses framing dan bentuk-bentuk aksi. McAdam et al. (1996) menjelaskan hubungan konsep-konsep tersebut diatas sebagai alat analisis dalam melihat gerakan sosial kontemporer secara empiris.

Konsep keluhan kolektif adalah bentuk ketidakpuasan terhadap ketidakadilan yang dirasakan atau diterima masyarakat luas, meskipun bukan satu-satunya yang mendorong terjadinya protes (Klandermans 2005). Struktur kesempatan politik adalah tanda-tanda yang konsisten pada tatanan politik yang memberi peluang pada aktor politik untuk membentuk sebuah gerakan sosial (Tarrow 1998). Keluhan kolektif dan struktur kesempatan politik memungkinkan organisasi gerakan sosial untuk mengembangkan struktur mobilisasi, yaitu seberapa besar dan kuat sumberdaya tersedia dan dapat dimobilisasi dengan tepat untuk mendukung gerakan (McCarthy \& Zald 1977). Snow dan Benford (2000) menjelaskan bahwa dalam konteks pertarungan wacana dan ide, organisasi gerakan mengembangkan proses framing yang dijelaskan sebagai upaya untuk meyakinan kelompok sasaran yang beragam dan publik secara luas sehingga mereka terdorong untuk turut mendesakkan sebuah perubahan.

Konsep-konsep tersebut diatas menentukan bagaimana ORNOP mampu mengembangkan bentuk-bentuk strategi dan aksi politik dalam rangka mendorong perubahan kebijakan dan tata kelola. Studi ini melihat bagaimana bentuk-bentuk aksi politik yang dikembangkan ORNOPmampu mendorong kesetaraan relasi kuasa antar aktor serta memberikan implikasi bagi perubahan kebijakan dan tata kelola pengendalian karhutla di Indonesia

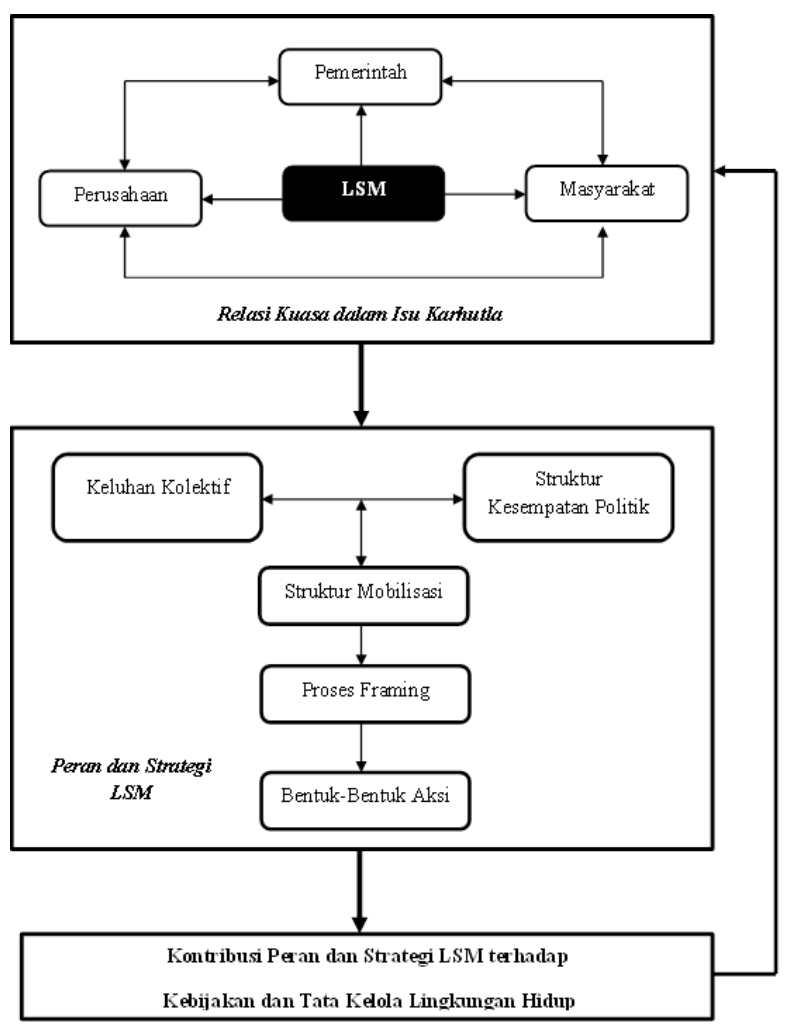

Gambar 1. Kerangka Pemikiran

\section{METODE PENELITIAN}

Penelitian menganut paradigma konstruktivisme dengan menggunakan pendekatan kualitatif untuk memberikan penjelasan dan memahami peristiwa yang sedang atau telah terjadi, yang menekankan pada interpretasi makna kategori yang berkembang dari informan penelitian (Denzin \& Lincoln 2009). Pendekatan kualitatif merupakan prosedur penelitian yang menghasilkan data deskriptif berupa katakata tertulis atau lisan. Metode pengumpulan data adalah dengan wawancara mendalam dan studi dokumen. Pemilihan informan dilakukan dengan teknik snow ball, dengan jumlah total informansebanyak 30 orang terdiri dari 17 orang pada tingkat nasional dan 11 orang pada tingkat lokal. Kriteria informan adalah para aktivis ORNOP yang duduk sebagai pimpinan dari organisasi ORNOP, akademisi, wartawan, perwakilan pejabat pemerintah baik pusat dan daerah, yang memiliki pengetahuan dan informasi terhadap kasus karhulta 
dan gerakan ORNOP lingkungan hidup. Penelitian dilakukan selama tiga bulan pada bulan April - Juni 2016, pada dua level yaitu pada tingkat nasional dan lokal. Penelitian pada tingkat nasional dilakukan di Jakarta dan Bogor, sementara penelitian pada tingkat lokal dilakukan di Jambi.

\section{HASIL DAN PEMBAHASAN}

\section{Ketimpangan Relasi Kuasa}

Studi menemukan bahwa berkembangnya karhutla terkait dengan masalah kebijakan dan kepentingan ekspansi industri berbasis hutan dan lahan. Kejadian karhutla skala luas di Indonesia adalah pada tahun 1982/1983, 1997/1998, 2006/2007 dan terakhir 2014/2015 tidak bisa dilepaskan dari proses-proses pembukaan hutan secara luas termasuk hutan rawa gambut. Gelombang pertama pembukaan hutan secara luas adalah sejak tahun 1970-an, dimana pemerintah memberikan izin secara besar-besaran kepada perusahaan kayu dalam skema Hak Pengusahaan Hutan (HPH) dan Hutan Tanaman Industri (HTI). Gelombang kedua adalah ekspansi perkebunan kelapa sawit sejak tahun 1990-an di Pulau Sumatra dan Kalimantan. Pada masa ini juga ditandai dengan proyek pembukaan lahan gambut sejuta hektar di Kalimantan Tengah pada periode 19951999 untuk kepentingan pertanian. Gelombang ketiga adalah terjadinya peningkatan permintaan produk kelapa sawit pada pasar global sejak tahun 2000, dimana kelapa sawit menjadi primadona ekspor untuk perolehan devisa negara. Indonesia tercatat sebagai produsen kelapa sawit global terbesar di dunia bersama dengan Malaysia.

Faktor-faktor diatas merupakan akar masalah dari karhutla. Ekspansi industri kayu dan perkebunan kelapa sawit mendorong meluasnya pembukaan lahan dengan cara membakar sebagai cara termurah bagi operasi perusahaan. Panjaitan (2015) menjelaskan bahwa selain praktek pembukaan lahan dengan cara membakar, pembangunan irigasi dan drainase pada rawa-rawa gambut mengakibatkan gambut mengalami penurunan permukaan (subsiden), dan rawan terjadi kebakaran. Kebakaran pada lahan gambut akan sulit dipadamkan karena merupakan kebakaran bawah (ground fire) sehingga api sulit diprediksi, bertahan dalam waktu yang lama serta menimbulkan konsentrasi asap yang lebih tebal.

Laporan dari KBPN (2015) mencatat bahwa di Provinsi Jambi, sebagian besar titik-titik api justru terjadi pada arealareal yang dibebani izin konsesi dibanding areal-areal kelola masyarakat. Laporan dari WARSI (2015) menunjukkan di Jambi terdapat hubungan antara areal kebakaran dengan lahanlahan yang sedang mengalami sengketa antara perusahaan dan masyarakat. Purnomo et al (2015) dalam studinya di Provinsi Riau, menggambarkan bahwa karhutla juga terkait dengan transaksi lahan terbakar untuk kepentingan pembukaan kebun kelapa sawit, dimana didalamnya berkaitan dengan kepentingan elit politik lokal.

Realita tersebut diatas menggambarkan bahwa dibalik karhutla terkandung persoalan ekonomi politik dan ketimpangan relasi kuasa, dimana kekuasaan dan kapital menjadi faktor pendorong terjadinya pembukaan hutan secara masif untuk kepentingan bisnis dan pasar. Studi menganalisis berbagai kebijakan yang terkait dengan karhutla sejak masa Orde Baru, Reformasi sampai dengan saat ini, dan menemukan bahwa karhutla dipandang sebagai persoalan sektoral, cenderung fokus pada langkah-langkah responsif dan insidental yang tidak terintegrasi dengan langkah-langkah pencegahan. Pada masa Orde Baru sampai dengan saat ini, kebijakan pencegahan karhutla bersanding dengan kebijakan yang justru mendorong ekspansi industri berbasis hutan dan lahan seperti perusahaan HPH/HTI dan perkebunan kelapa sawit. Kebijakan pencegahan karhutla disinggung dalam peraturan perundangan, namun lebih pada larangan-larangan dan pedoman teknis untuk menghidari pembakaran lahan tanpa disertai dengan kapasitas pemantauan dan penegakkan hukum terhadap perusahaan pembakar hutan dan lahan.

Penjelasan diatas memberikan gambaran bahwa upaya untuk pengendalian karhutla tidak berlangsung secara signifikan, dimana motif dan kepentingan ekonomi lebih dominan dibanding dengan kepentingan untuk mencegah karhutla secara fundamental. Perusahaan merupakan aktor dominan, sementara kalangan masyarakat sipil termasuk warga masyarakat merupakan pihak yang belum mendapatkan ruang untuk menentukan arah kebijakan dan tata kelola. Warga masyarakat justru menjadi korban dari dampak-dampak langsung karhutla. Ketimpangan relasi kuasa tersebut, menjadi akar masalah karhutla sehingga selama lebih dari 17 tahun karhutla terus terjadi dengan intensitas semakin tinggi dan dampak semakin luas.

\section{Keluhan Kolektif dan Struktur Kesempatan Politik}

Dalam kondisi ketimpangan relasi kuasa pada kasus karhutla, ORNOP memainkan peran dalam rangka mendorong perubahan kebijakan dan tata kelola. Dengan menganalisis tanggapan ORNOP terhadap kejadian karhutla pada tahun 1982/1993, 1997/1998, 2006/2007 dan 2014/2015, studi ini menemukan bahwa tersedianya keluhan kolektif dan terbukanya struktur kesempatan politik menentukan tumbuhnya peran ORNOP dalam menanggapi karhutla. Pada kejadian karhutla tahun 1982/1983, keluhan kolektif secara luas belum terjadi sehubungan dengan karhutla yang terjadi pada skala lokal di Provinsi Kalimantan Timur. Pada masa itu struktur kesempatan politik masih tertutup dimana kekuasaan politik pemerinta Orde Baru yang represif tidak memungkinkan ORNOP untuk secara terbuka melakukan protes terhadap kebijakan. Organisasi advokasi seperti WALHI baru berdiri pada tahun 1980, sementara WWF di Indonesia masih merupakan kantor perwakilan WWF Internasional dibawah pengawasan Departemen Kehutanan.

Kasus karhutla terbesar sepanjang sejarah terjadi pada tahun 1997/1998 yang menghanguskan lahan seluas 11,7 juta hektar dan terjadi secara luas di Kalimantan, Sumatra, Jawa, Bali, Sulawesi dan Nusa Tenggara (Panjaitan 2015). Dampak kabut asap menimbulkan keluhan kolektif yang luas dalam masyarakat. Pada masa ini struktur kesempatan politik mulai terbuka menjelang kejatuhan pemerintah Orde Baru. WALHI secara terbuka melakukan kritik terhadap kebijakan pembukaan lahan gambut sejuta hektar di Kalimantan Tengah, serta melakukan investigasi dan gugatan terhadap perusahaan pembakar lahan di Sumatra Selatan pada tahun 1999.

Kejadian karhutla skala luas pada masa reformasi terjadi pada tahun 2006/2007 dan pada tahun 2014/2015. Keluhan kolektif semakin meluas dengan berkembangnya pemberitaan media massa dan media sosial. Menurut Nugroho dan Syarif (2014) perkembangan media massa dan internet merupakn faktor penting dalam mendorong aktivisme publik di media atau disebut sebagai "click activism". Struktur kesempatan politik terbuka luas, dengan semakin terbukanya pemerintah terhadap masukan-masukan dari kalangan ORNOP. Perkembangan jaringan advokasi transnasional memungkinkan terjadinya kerjasama ORNOP lintas negara, untuk saling bertukar 
informasi, pengatahuan dan layanan untuk menanggapi masalah-masalah lingkungan hidup (Karimasari 2013; Guadalope \& Rodrigues 2014).

\section{Stuktur Mobilisasi}

Tersedianya keluhan kolektif dan terbukanya kesempatan politik merupakan kondisi pemungkin bagi ORNOP untuk mengembangkan struktur mobilisasi. Struktur mobilisasi berkaitan dengan seberapa besar dan kuat sumberdaya tersedia dan dapat dimobilisasi dengan tepat untuk mendukung gerakan, termasuk didalamnya aspek organisasi, jaringan, taktik dan pendanaan (McCarthy dan Zald 1977).

Studi menemukan pada tingkat nasional, struktur mobilisasi dibangun dalam bentuk kerjasama taktis antar ORNOP. Koalisi taktis tersebut dikembangkan dalam rangka untuk penyampaian pernyataan sikap bersama terkait kasus karhutla dalam bentuk petisi, konferensi pers dan kerjasama dalam lobi-lobi kepada pemerintah. WALHI dan Greenpeace pada tanggal 28 Oktober 2014 menyampaikan petisi online melalui paltform change.org dan surat resmi kepada Presiden RI untuk meminta Presiden Jokowi "blusukan asap". Petisi mendapat tanggapan dari Presiden yang melakukan kunjungan ke Riau pada tanggal 27 November 2014, untuk secara langsung melihat kondisi lapangan terkait dengan kasus karhutla. Pada tanggal 24 Oktober 2015 ketika masa puncak kabut asap akibat karhutla terjadi, Presiden mengundang para pimpinan ORNOP seperti WALHI, Greenpeace dan beberapa ORNOP lainnya untuk mendapatkan masukan-masukan dalam rangka penyelesaian masalah karhutla. Koalisi juga dibentuk atas dasar kepentingan taktis untuk melihat sasaran-sasaran baru dalam kasus karhutla, seperti terbangannya Koalisi Responsive Bank untuk mempengaruhi aliran kapital kepada perusahaan pembakar lahan.

Pada tingkat nasional struktur mobilisasi yang dibangun berdasarkan pada kepentingan koalisi taktis, dimana ORNOP pada tingkat nasional memiliki agenda politik masingmasing. ORNOP lebih memerankan diri sebagai kelompok kepentingan yang melakukan advokasi, kampanye dan lobi, dengan menggunakan karhutla sebagai momentum untuk pembenahan tata kelola lebih luas.

Pada tingkat lokal di Jambi, studi menemukan bahwa ORNOP seperti KKI Warsi, WALHI Jambi dan Yayasan Lembaga Bantuan Hukum Lingkungan (YLBHL) mampu memanfaatkan keluhan kolektif dan struktur kesempatan politik untuk membangun struktur mobilisasi dalam bentuk Koalisi Jambi Melawan Asap (KJMA). Berbeda dengan tingkat nasional, kalangan aktivis ORNOP di Jambi juga sekaligus sebagai korban dari bencana kabut asap. Situasi tersebut mendorong terbangunnya KJMA dimana anggotanya tidak hanya kalangan ORNOP namun juga organisasi-organisasi lain seperti organisasi mahasiswa, kalangan seniman, organisasi profesi seperti dosen, dokter dan advokat, organisasi perempuan, organisasi tani dan lain sebagainya. Struktur mobilisasi ini mampu membangun protes kolektif untuk menekan pemerintah daerah, memobilisasi bantuan masker, obatobatan dan makanan dalam rangka penanganan korban kabut asap, melakukan investigasi bersama terhadap pelanggaran perusahaan yang membakar lahan, menyampaikan gugatan hukum dan mendorong lahirnya regulasi terkait dengan karhutla pada tingkat provinsi. Pada tingkat lokal, ORNOP mampu memerankan diri sebagai organisasi gerakan sosial yang mendorong tumbuhnya aksi-aksi kolektif, jaringan lintas kelembagaan dan identitas kolektif sebagai sesama korban kabut asap.

Studi menemukan bahwa ORNOP memiliki agenda politik masing-masing, dan memanfaatkan karhutla sebagai momentum dalam rangka menjalankan peran-peran untuk mendorong pembenahan tata kelola hutan dan lahan. Keragaman peran ORNOP merupakan sebuah bentuk struktur mobilisasi dimana ORNOP memanfaatkan kapasitas dan kompetensi mereka dalam mengisi ruang-ruang partisipasi dalam rangka mendorong perubahan tata kelola. Bentukbentuk peran antara lain adalah peran advokasi kebijakan, kampanye publik, penguatan kapasitas dan konsultasi, pengelolaan pengetahuan dan implementor di lapangan.

Peran advokasi kebijakan paling menonjol dilakukan oleh organisasi advokasi lingkungan hidup yang dimotori oleh WALHI, Greenpeace dan Sawit Watch. Dalam konteks ini ORNOP memerankan diri untuk melakukan "politik pertentangan" atau contentious politic, istilah yang diperkenalkan oleh Tarrow (1999) yakni ketika masyarakat biasa terlibat dalam perlawanan politik dengan kekuatan elit, pemegang otoritas dan lawan-lawan politik lainnya. Dalam konteks ini, ORNOP melakukan gugatan kepada perusahaan dan pemerintah, yang dianggap sebagai pihak-pihak yang bertanggung jawab terkait dengan kejadian karhutla.

Peran kampanye publik dilakukan oleh organisasi seperti Greenpeace dan WWF Indonesia yang memiliki reputasi dalam organisasi kampanye lingkungan hidup. Greenpeace secara aktif melakukan kampanye publik pada tingkat nasional dan internasional untuk melakukan tekanan kepada pemerintah dan perusahaan agar mengadopsi prinsip "nol deforestasi" (zero deforestation). Dengan jaringan internasional yang dimiliki Greenpeace mengangkat kasus karhutla pada forum-forum perundingan internasional dan memanfaatkan media massa nasional dan global untuk menekan pemerintah, perusahaan dan pasar agar mampu menerapkan standar pengelolaan lingkungan hidup untuk mencegah terjadinya karhutla.

WWF Indonesia merupakan satu ORNOP yang menggunakan kapasitas untuk melakukan perbaikan "dari dalam sistem". WWF Indonesia menjalankan peran konsultasi dan penguatan kapasitas kepada pemerintah dalam rangka mendorong integritas dan peningkatan kapasitas dalam penanganan masalah karhutla. Melalui program-program lapangan, WWF Indonesia mengembangkan pendekatan multipihak dalam rangka pencegahan korupsi kehutanan, penguatan tata ruang berbasis ekosistem, penguatan kapasitas lokal serta mendorong lahirnya regulasi-regulasi dalam rangka mencegah terjadinya kasus karhutla.

Studi menemukan bahwa beberapa ORNOP memfokuskan peran pada pengelolaan pengetahuan. Peran ini meliputi melakukan kajian dan riset, mengelola informasi dan pengetahuan, serta melakukan penyebaran informasi terkait dengan isu-isu karhutla. ORNOP seperti Epistema Institute dan Forest Wacth Indonesia adalah contoh ORNOP yang menjalankan peran ini. Greenpeace mulai menjalankan peran pengelolaan pengetahuan dengan mengembangkan peta konsesi perusahaan yang dikemas dalam bentuk interaktif yang mereka sebut sebagai "Kepo Hutan", sehingga publik secara langsung mampu memantau perusahaan pembakar hutan dan lahan.

Beberapa organisasi memobilisasi peran sebagai implementor lapangan. WWF Indonesia bekerjasama dengan Taman Nasional Sebangau mengembangan model pengelolaan sekat 
kanal gambit berbasis masyarakat. Beberapa ORNOP lokal di Jambi seperti KKI Warsi, Mitra Aksi, Gita Buana dan CAPPA mengembangkan kegiatan untuk pendampingan masyarakat dalam rangka membangun model kelola masyarakat untuk pencegahan karhutla di lahan gambut.

\section{Proses Framing}

Perkembangan peran ORNOP juga ditentukan berkembangnya kapasitas organisasi ORNOP dalam melakukan framing masalah. Proses framing adalah upaya untuk meyakinkan kelompok sasaran yang beragam dan publik secara luas sehingga mereka terdorong untuk mendesakkan sebuah perubahan (Snow \& Benford 2000). Kemampuan ORNOP dalam melakukan framing masalah karhutla terus berkembang dari waktu ke waktu.

Pada kasus karhutla tahun 1997/1998, ORNOP melihat masalah karhutla sebagai persoalan kegagalan kebijakan kehutanan dalam melindungi lahan gambut. Pada kasus karhutla tahun 2006/2007, framing berkembang dengan tidak hanya pada masalah kebijakan, namun juga terkait dengan kepentingan rantai pasokan pasar global. Pada tahun 2009, Greenpeace berhasil mengangkat framing tersebut dengan melakukan kampanye publik yang menyerang grup perusahaan Sinar Mas yang dituduh melakukan pembakaran hutan. Greenpeace berhasil memutus rantai pasokan, dimana perusahaan besar seperti Nestle dan Unilever melakukan pemutusan kontrak pembelian produk kelapa sawit dari Golden Agri Resources (GAR) yang merupakan salah satu divisi perusahaan milik grup Sinar Mas (GSEA 2010).

Pada kejadian karhutla 2014/2015, framingORNOP dalam karhutla semakin luas dan beragam. WALHI mengembangkan framing bahwa karhutla adalah bentuk kejahatan korporasi (corporate crime), sementara WWF mengembangkan framing korupsi kehutanan. Aliansi yang diberi nama ResponsiBank beranggotakan Prakarsa, WALHI, INFID, TUK Indonesia, YLKI, ICW untuk melakukan advokasi dengan titik fokus pada pembiayaan perbankan yang mendanai perusahaanperusahaan yang membakar lahan. Kelompok ORNOP ini melakukan framing bahwa "bank turut membakar hutan" sebagai cara untuk mempengaruhi aliran kapital kepada perusahaan yang melakukan praktek-praktek pembakaran hutan dan lahan gambut.

\section{Strategi Politik dan Bentuk Aksi}

Struktur mobilisasi dan proses framing menentukan ragam strategi politik dan bentuk-bentuk aksi yang dilakukan ORNOP dalam menanggapi karhutla. Studi menemukan strategi politik ORNOP dalam menanggapi karhutla. Pertama adalah mendorong perubahan secara langsung pada sasaran. Hal ini dilakukan dalam dua bentuk aksi yaitu : (1) mendesak pemerintah untuk mengeluarkan regulasi yang melindungi hutan dan lahan gambut; (2) menggugat perusahaan secara hukum dan menyerang perusahaan pembakar lahan dengan kampanye publik dan pembentukan opini di media massa. WALHI dan jaringan mereka di daerah seperti di Jambi, Riau dan Sumatera Selatan melakukan gugatan secara hukum kepada perusahaan pembakar lahan.

Strategi kedua, adalah menggunakan jaringan advokasi internasional. ORNOP memanfaatkan jaringan advokasi internasional untuk mengangkat kasus karhutla pada tingkat internasional, misalnya pada forum perundingan perubahan iklim di Paris sebagai cara untuk menghasilkan tekanan-tekanan kepada pemerintah dari luar atau disebut sebagai boomerang effect (Keck \&Sikkink 1999). Stategi politik ketiga adalah menggunakan kekuatan pasar. Hal ini dilakukan Greenpeace mempengaruhi pasar dan konsumen agar memutus pembelian produk kelapa sawit dari perusahaan yang membakar hutan dan lahan. Hal yang sama dilakukan oleh Sawit Watch dan WWF Indonesia dengan keterlibatan mereka pada RSPO untuk mendorong perusahaan mematuhi standar pengelolaan lingkungan hidup dan sosial. Keempat adalah mempengaruhi aliran kapital. Walhi, TUK Indonesia, Perkumpulan Prakarsa dan beberapa ORNOP lain mengembangkan koalisi dengan sasaran untuk mempengaruhi lembaga-lembaga pembiayaan dan perbankan untuk tidak mendanai perusahaan-perusahaan yang membakar lahan dan hutan.

Kelima adalah memanfaatkan dukungan elit pemerintahan. Strategi ini semakin berkembang pada masa pemerintahan Presiden Joko Widodo, dimana beberapa aktivis ORNOP masuk dalam lingkaran kekuasaan pemerintah. Hal tersebut memungkinkan ORNOP memberikan masukan-masukan mengenai kebijakan dalam rangka pengendalian karhutla. Terakhir yang keenam adalah mengangkat praktik-praktik terbaik. Hal ini dilakukan untuk mempromosikan pendekatan dan model pada tingkat tapak, sebagai tandingan terhadap program pemerintah yang tidak mampu menjawab masalah karhutla. Hal ini dilakukan WWF Indonesia yang mengangkat model pengelolaan lahan gambut berbasis masyarakat di Sebangau Kalimantan Tengah. Mitra Aksi di Jambi mengembangkan model yang mengkombinasikan pengelolaan gambut dengan pertanian berkelanjutan.

\section{Implikasi pada Tata Kelola}

Beragam strategi politik dan bentuk-bentuk aksi dari ORNOP memberikan pengaruh terhadap penguatan tata kelola dalam rangka pengendalian karhutla di Indonesia. ORNOP menggunakan karhutla untuk mendorong perubahan tata kelola lebih luas mulai dari kebijakan, penegakan hukum, pasar dan perilaku sektor swasta, serta mendorong praktikpraktik lokal berbasis masyarakat. Dalam konteks kebijakan ORNOP mampu mendorong lahirnya regulasi, sebagai contoh adalah peran ORNOP di Jambi mampu menghasilkan Peraturan Daerah Provinsi No. 2 tahun 2015 tentang Pencegahan dan Pengendalian Kebakaran Hutan dan Lahan, yang merupakan perda karhutla pertama di Indonesia. ORNOP mampu memberikan masukan-masukan kepada pemerintah sehingga lahan gambut ditangani secara khusus dalam sebuah badan dibawah Presiden. Melalui Perpres No 1 Tahun 2016, pemerintah membentuk Badan Restorasi Gambut (BRG) sebagai untuk percepatan pemulian kawasan dan pengembalian fungsi hidrologis gambut sebagai upaya pencegahan dan pengendalian kebakaran hutan dan lahan. Beberapa aktivis ORNOP masuk menjadi unsur pimpinan dalam BRG.

Dalam konteks penegakkan hukum, ORNOP seperti WALHI melakukan gugatan terhadap perusahaan-perusahaan yang dianggap melakukan pembakaran hutan dan lahan. Upaya ini bersinergi dengan pemerintah dimana Kementerian LHK melakukan kajian dan investigasi terhadap 413 perusahaan, dan 56 telah diduga melakukan pembakaran dan 16 diantaranya sudah dikenai sangsi pembekuan izin, pencabutan hak usaha dan izin lingkungan serta sanki penguasaan lahan oleh pemerintah.

ORNOP mampu mempengaruhi standar pengelolaan lingkungan hidup dalam rangka pencegahan karhutla, seperti dilakukan Greenpeace, Sawit Watch dan WWF Indonesia 
yang aktif dalam memantau perusahaan kelapa sawit untuk menerapkan skema Rountable on Sustainbale Palm Oil (RSPO) dan Indonesia Palm Oil Pledge (IPOP). Beberapa ORNOP tergabung dalam ResponsiBank untuk mempengaruhi perbankan dalam mendanai perusahaan pembakar lahan. ORNOP lokal di Jambi seperti Mitra Aksi, CAPPA dan Gita Buana mengembangkan pendampingan kepada masyarakat untuk mengembangkan pengelolaan lahan gambut berbasis pada penghidupan masyarakat lokal.

\section{KESIMPULAN DAN SARAN}

\section{Kesimpulan}

ORNOP merupakan salah satu bentuk organisasi gerakan sosial yang mampu mengembangkan peran dan strategi dalam rangka memperkuat tata kelola pengendalian karhutla di Indonesia. ORNOP mampu memanfaatkan tersedianya keluhan kolektif dan terbukanya struktur kesempatan politik untuk membangun struktur mobilisasi dalam lingkup peran advokasi kebijakan, kampanye publik, pengembangan kapasitas dan konsultasi, pengelolaan pengetahuan dan implementor lapangan.

Strategi politik ORNOP adalah mempengaruhi langsung sasaran perubahan, menggunakan jaringan advokasi transnasional, mempengaruhi aliran kapital, memanfaatkan dukungan elit pemerintahan, serta mempromosikan praktikpraktik terbaik pada tingkat lokal. Upaya tersebut memberikan pengaruh dalam bentuk lahirnya regulasi, memperkuat upaya penegakan hukum, mempengaruhi perilaku sektor swasta serta mendorong tumbuhnya praktik-praktik lokal dalam pengelolaan lahan gambut berbasis masyarakat.

Strategi politik ORNOP tersebut dikembangkan dalam rangka mendorong kesetaraan dalam relasi kuasa diantara para aktor dalam konteks kasus karhutla. Peran dan strategi ORNOP memiliki implikasi penting dalam rangka penguatan kebijakan dan tata kelola pengendalian karhutla di Indonesia.

\section{Saran}

Studi tentang ORNOP khususnya dan ranah gerakan sosial secara umum perlu untuk dikembangkan untuk memperkaya pengetahuan sosiologi. Penggunaan konsep dan teori gerakan sosial memberikan peluang untuk mengkaitkan studi ekologi politik dengan perubahan kebijakan publik dan tata kelola lingkungan hidup. Untuk itu studi ini perlu dilanjutkan dengan penelitian-penelitian yang lebih mendalam mengenai dinamika ORNOP pada lingkup peran tertentu dan kasuskasus lingkungan hidup di Indonesia.

\section{DAFTAR PUSTAKA}

[BD] Bank Dunia. 2015. Laporan Triwulanan Ketiga Perekonomian Indonesia Periode Juni - Oktober 2015. Jakarta (ID) : Bank Dunia.

Blaikie P, Brookfield H. 1987. Land Degradation and Society. London (UK) : Matheuen.

Bryant RL, Bailey S. 1997. Third World Political Ecology. London (UK) : Routlegde.

Carter N. 2007. The Politics of Environment : Ideas, Activism and Policies. Cambridge (GB): Cambridge University Press.

Dezlin NK, S Licoln YS. 2009. Handbook of Qualitative Research. Dariyatno, penerjemah. Yogyakarta (ID): Pustaka Pelajar.

Diani M, Porta DD. 2006. Social Movement : An Introduction. Oxford (UK) : Blackwell Publishing.
FakihM. 1996. Masyarakat Sipil untuk Transformasi Sosial: Pergolakan Ideologi di Dunia ORNOP Indonesia. Yogyakarta (ID) : Pustaka Pelajar

Ganie-Rochman M. 2002. An Uphill Struggle : Advocacy NGOs under Soeharto's New Order. Jakarta (ID). Laboratorium Sosio FISIP UI.

[GSEA] Greenpeace South East Asia. 2010. Bagaimana Sinar Mas Meluluhkan Bumi. Amsterdam (NL) : Greenpeace International.

Guadalope M, Rodrigues M. 2004. Global Environtalism and Local Politics : Transnasional Advocacy Networks in Brazil, Ecuador dan India. New York (US) : State University of Network Press.

[KBPN] Kanwil BPN Provinsi Jambi. 2015. Titik Api (Hotspot) dalam Perspektif Pertanahan di Provinsi Jambi. Jambi (ID) : Kanwil BPN Provinsi Jambi.

Keck M, Sikkink K. 1999. Transnational Network in International and Regional Politics. New York (US) : UNESCO.

Klandermans B. 2005. Protes dalam Kajian Psikologi Sosial. Yogyakarta (ID) : Pustaka Pelajar.

McAdam D, McCarhty J, Mayer Z. 1996. Comparative Perspectives on Social Movements : Political Opportunities, Mobilizing Structures and Cultural Framings. Cambridge (UK) : Cambridge University Press.

McAdam D, Snow D. 1997. Social Movements : Reading on Their Emergence, Mobilization and Dynamic. New York (US) : Roxbury Publising Company.

Nugroho Y, Syarif SS. 2012. Beyond Klik-Activism? New Media and Political Process in Contemporary Indonesia. Berlin (DE) : Friedrich-Ebert-Stiftung.

Peluso NL, Afiff S, Rahman NF 2008. Claiming the Grounds : Agrarian and Environmental Movement in Indonesia. $J$. Agrarian Reform 8 : 377-407.

Princen T, Finger M. 1994. Environmental NGOs in World Politics : Linking the Local and the Global. New York (US) : Routledge.

Panjaitan, R. 2015. Dampak, Upaya dan Harapan Akibat Kebakaran Hutan Tahun 2015 [Makalah]. Hari Pulang Kampung Fakultas Kehutanan IPB; 2015 Nov 7; Bogor Indonesia. Bogor (ID) : Fakultas Kehutanan IPB.

Purnomo H, Shantiko B, Gunawan H, Gaveau D, Sitorus S, Salim MA, Achdiawan R. 2015. Ekonomi Politik Kebakaran Hutan dan Lahan di Riau : Sebuah Pendekatan Analitis [Makalah]. Mencegah Kebakaran Hutan dan Lahan; 2015 Jun 11; Jakarta Indonesia. Jakarta (ID) : Yayasan Sarana Wana Jaya.

Rachman NF. 2005. Memahami Gerakan Gerakan Rakyat Dunia Ketiga. Yogyakarta (ID) : Insist Press.

Saunders C. 2013. Environmental Networks and Social Movement Theory. London (UK) : Bloomsbury Academy.

Situmorang AW. 2013. Dinamika Protes Kolektif Lingkungan Hidup di Indonesia (1968-2001). Yogyakarta (ID) : Pustaka Pelajar.

Singh R. 2001. Social Movement, Old and New : A Postmodernist Critique. London (UK) : Sage Publication.

Snow DA, Benford RD. 2000. Framing Processes and Social Movements : An Overview and Assessment. J Annual Review of Sociology 26:611-639.

Tarrow S. 1998. Power in Movement: Social Movements and Contentious Politics. Cambridge (UK) : Cambridge University Press.

[WARSI] KKI WARSI. 2015. Studi Valuasi Dampak Kebakaran Gambut di Kabupaten Tanjung Jabung Timur, Tanjung Jabung Barat dan Muaro Jambi, Provinsi Jambi[laporan]. Jambi (ID) : KKI WARSI. 